\title{
1991 ANNUAL MEETING CHILD CARE SERVICE
}

The American Political Science Association will sponsor a Child Care Service at the 1991 Annual Meeting in Washington, D.C., August 29 - September 1, 1991. This service is offered at no charge for unlimited use to children of registrants at the 1991 Annual Meeting. In order to reserve a place, a $\$ 25$ non-refundable deposit per child is required with pre-registration.

Beginning on Thursday, August 29, the service will be available daily in the Washington Hilton. The hours are 8:00 a.m. to 10:00 p.m., except on Sunday, September 1 when the hours are adjusted to 8:30 a.m. to 12:30 p.m. Snacks will be available for the children.

Parents will be asked to complete a tentative schedule following their pre-registration for child care service. Children must be picked up promptly at the appointed time. Diapers, special milk or formula, as well as any written special feeding isntructions should be supplied by the parents. Lunch and/or dinner must be provided by the parents.

If your child has a favorite toy or game, it should be labeled with the child's name and the caretakers will do their best to see that it is returned. However, responsibility for the loss of any personal property cannot be assumed.

Parents' Name:

Home Address:

Home Phone:

Child/Children Name(s), Age(s), Weight:

1.

2.

3.

We, the parents of (the children listed above), hereby give our consent to any licensed physician at, with, or from any accredited hospital to administer any medical care or medication to the above named child/children during our absence from them while attending the American Political Science Association Annual Meeting at the Washington Hilton and Towers, Washington, D. C. , August 29 - September 1, 1991.

Mother's signature:

Father's signature:

\section{ALL CHILDREN WHO USE THE SERVICE MUST BE PRE-REGISTERED WITH DEPOSIT FOR EACH CHILD RECEIVED BY JULY 15, 1991. THERE WILL BE LIMITED ON-SITE REGISTRATION AT A \$40 FEE.}

List name, address, and telephone number of any legal next of kin we may contact if you are unreachable. If this contact is necessary, a collect telephone call will be placed to the next of kin listed below for notification.

Name, City, State, Area Code and Telephone Number

\author{
Return completed forms to: \\ Child Care Coordinator \\ American Political Science Association \\ 1527 New Hampshire Avenue NW \\ Washington, D.C. 20036
}

Please return this form no later than July 15, 1991. 